\title{
Activity patterns of the soprano pipistrelle Pipistrellus pygmaeus throughout the year in southern Norway
}

\author{
Karl Frafjord
}

\begin{abstract}
Background: Most temperate bats are regular hibernators in the winter. Knowledge about the length of their active season and how they adjust their nightly activity throughout the season, is critical to conservation. The characteristics of these are likely to vary with climate as well as latitude. This study investigated the flight activity of the soprano pipistrelle Pipistrellus pygmaeus in Frafjord, a small valley in the south-western corner of Norway $\left(58^{\circ}\right.$ $\left.50^{\prime} \mathrm{N} 6^{\circ} 18^{\prime} \mathrm{E}\right)$ with an oceanic climate.

Results: Activity was recorded with an ultrasound recorder throughout April 2018 to June 2019 at one site, with supplemental recordings in March to June 2020, i.e., covering all months of the year. Recordings at other nearby sites were made in the summers (June-August) of 2016, 2017, 2019 and 2020, as well as some of the last days in December 2019 to the first days of January 2020. Overall, soprano pipistrelles were recorded flying in all months of the year, but very few in December-March. Regular activity was recorded from late April or early May until late October, and some recordings were also made in November. The highest numbers of recordings were made in August and September. Social calls, i.e. male song flights, were recorded from April to November, with the vast majority in August and September. Nearly all recordings were made between sunset and sunrise.

Conclusions: The soprano pipistrelle in this region showed regular activity through 6-7 months of the year. It adjusted its activity to the changing night length throughout the year, closely following sunset and sunrise. It was rarely recorded flying before sunset and almost never after sunrise. Most activity was recorded in the middle of the night, and social calls also followed this trend closely. Harems in late summer and autumn were confirmed in a bat box, which was also used for winter hibernation.
\end{abstract}

Keywords: Activity, Foraging, Social calls, Yearly variation, Hibernation

\section{Background}

Insectivorous bats have evolved a number of adaptations. Among these are flight, echolocation, nocturnal hunting and hibernation. Several hypotheses have been suggested to explain their nocturnal hunting strategy; avoiding diurnal predators, avoiding competition with insectivorous birds or avoiding high daytime

\footnotetext{
Correspondence: karl.frafjord@uit.no

Tromsø University Museum, UiT The Arctic University of Norway, P. O. Box 6050 Langnes, 9037 Tromsø, Norway
}

temperatures [1-3]. Among these, predator avoidance appears to be most widely supported [4-6]. Because bats in temperate regions hibernate during the winter, they basically fly in only part of the year. Most of these bats also enter daily torpor as a means to save energy, especially in inclement weather [7]. For females, the costs of pregnancy and lactation are high, and they may prefer to avoid torpor in these periods [7]. Torpor may extend pregnancy, delay birth and reduce milk production.

(c) The Author(s). 2021 Open Access This article is licensed under a Creative Commons Attribution 4.0 International License, which permits use, sharing, adaptation, distribution and reproduction in any medium or format, as long as you give appropriate credit to the original author(s) and the source, provide a link to the Creative Commons licence, and indicate if changes were made. The images or other third party material in this article are included in the article's Creative Commons licence, unless indicated otherwise in a credit line to the material. If material is not included in the article's Creative Commons licence and your intended use is not permitted by statutory regulation or exceeds the permitted use, you will need to obtain permission directly from the copyright holder. To view a copy of this licence, visit http://creativecommons.org/licenses/by/4.0/. The Creative Commons Public Domain Dedication waiver (http://creativecommons.org/publicdomain/zero/1.0/) applies to the data made available in this article, unless otherwise stated in a credit line to the data. 
Pipistrelle bats, Pipistrellus spp., are very small and often very numerous. Whereas several studies address the activity and behaviour of the common pipistrelle $P$. pipistrellus [8-15], little is known about other pipistrelle species $[16,17]$. The common and soprano pipistrelles P. pygmaeus were, for example, only identified and separated in the 1990's [18]. Earlier studies were of uncertain species, although it is likely that most involved the common pipistrelle.

The soprano pipistrelle is common in South Norway [19] and appears to hunt in brighter light than most other bats in this region. It may emerge before sunset at $62^{\circ} \mathrm{N}$, but then it hunted inside the forest and not in the open until the night became dark [20,21]. This contrasts with the behaviour of the common pipistrelle, which emerge well after sunset [8]. Russo et al. [22] verified this difference between the two species and confirmed that forest habitat was used by early hunting soprano pipistrelles. In other habitats the soprano pipistrelle may emerge later and after sunset [23].

Hollow trees or rock crevices are probably the natural nursery roosts of the soprano pipistrelle in Norway, but when available it prefers warmer, man-made structures such as buildings and bat boxes [24]. Weather influences pipistrelles in a multitude of ways, both in their ecology and behaviour $[17,25]$. The common pipistrelle may hunt also during the winter months, particularly in warm and calm weather [26].

Male pipistrelles of all species have characteristic "mating" displays, using particular vocalisations and behaviours to announce their presence and to attract females $[27,28]$. These vocalisations are called social calls and are emitted by both common and soprano pipistrelle males during prolonged song-flights. However, Barlow \& Jones [29] concluded that these social calls were used in food defence when insects are scarce rather than in social displays [30].

This study describes the nocturnal activity of the soprano pipistrelle throughout the year and through the night. The main aims were to study how this bat adjusts its activity to the changing night length and the timing of the males' social calls.

\section{Results}

The sample sizes were: echolocation recordings of soprano pipistrelles at the main site $n=20,732 \mathrm{~min}$, social calls at the main site $n=7036 \mathrm{~min}$, and echolocation recordings at other sites $n=3194 \mathrm{~min}$. The first soprano pipistrelle in 2018 was recorded in February (Fig. 1). Very few were registered in February, March and December, and relatively few in April and November (Table 1). Numbers increased from April to September, and declined in October and very much so in November.

To further examine whether the pipistrelle could also be flying in late December to January, some extra recordings were made in the period 22 December 2019 to 4 January 2020 at the bat box. This confirmed flying pipistrelles (Table 2). Additionally, two pipistrelles were observed flying at the farm on 2 January 2020 at $1815 \mathrm{~h}$ $\left(8^{\circ} \mathrm{C}\right.$, insects were also seen flying). The ultrasound recordings confirmed occasional hunting (feeding buzzes) in winter. Flights in December 2019 to January 2020 were confirmed by changing numbers of pipistrelles in

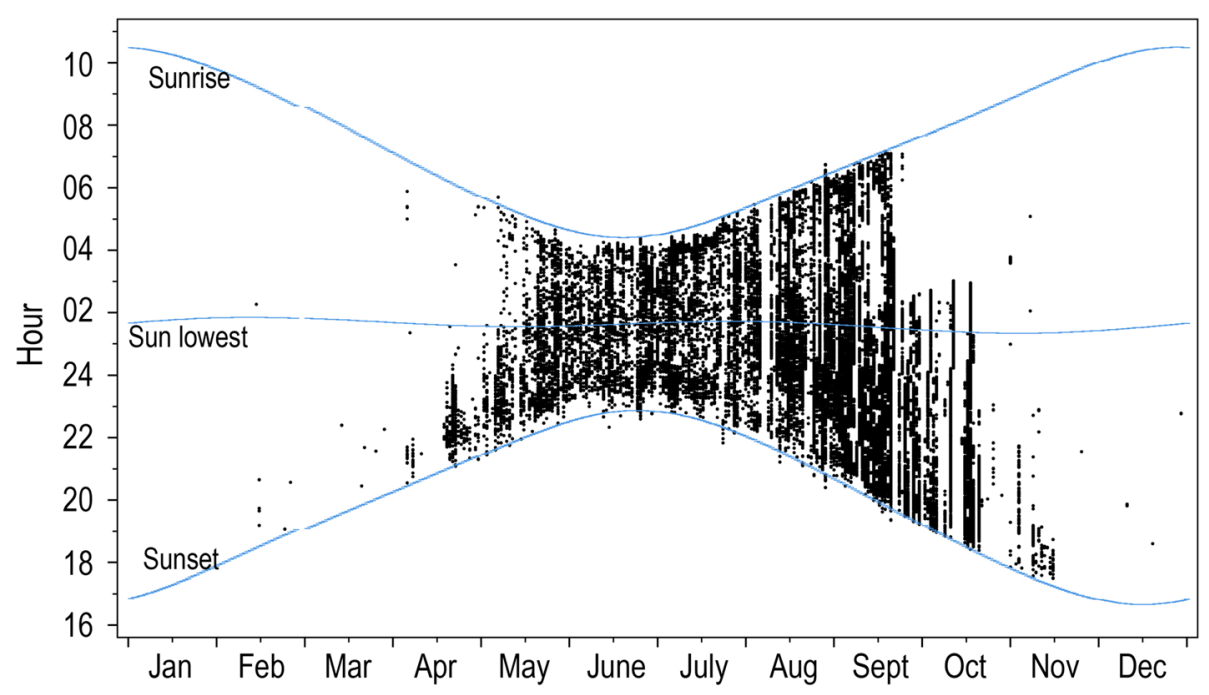

Fig. 1 Distribution of soprano pipistrelle recordings during the night across the year in Frafjord, SW Norway. The lower line represents sunset, the upper line represents sunrise and the central line represents the sun at its lowest angle. Each point represents a 1 min interval in which bats were recorded. Note that many points are superimposed. Recordings were not made in the last part of the night from the last days of September to December 
Table 1 Earliest and latest times (local summer time, $24 \mathrm{~h}$ clock) soprano pipistrelles were recorded by month

\begin{tabular}{|c|c|c|c|c|c|}
\hline Month & First time & Last time & $\begin{array}{l}\mathrm{N} \\
\min \end{array}$ & $\begin{array}{l}\text { Lux in } \\
22 \mathrm{~h}\end{array}$ & $\begin{array}{l}\text { Lux in } \\
23 \mathrm{~h}\end{array}$ \\
\hline \multicolumn{6}{|c|}{ Main site } \\
\hline Feb & 1904 & 0216 & 7 & & \\
\hline Mar & 2027 & - & 5 & & \\
\hline Apr & 2033 & 0553 & 342 & & \\
\hline May & 2127 & 0542 & 1938 & & \\
\hline June & 2240 & 0415 & 2002 & 1050 & 560 \\
\hline July & 2234 & 0458 & 2052 & 970 & 290 \\
\hline Aug & 2047 & 0618 & 3707 & 530 & 70 \\
\hline Sep & 1913 & 0710 & 7935 & & \\
\hline Oct & 1751 & - & 2525 & & \\
\hline Nov & 1730 & - & 216 & & \\
\hline Dec & 1836 & - & 5 & & \\
\hline \multicolumn{6}{|c|}{ Other sites } \\
\hline June & 2236 & 0423 & 629 & & \\
\hline July & 2150 & 0512 & 1207 & & \\
\hline Aug & 2024 & 0645 & 1358 & & \\
\hline
\end{tabular}

The times are based on recordings at the main site and other sites in Frafjord, SW Norway. $\mathrm{N}=$ sample size in minutes. Maximum lux in the $22 \mathrm{~h}$ (i.e. $2200-$ $2259 \mathrm{~h}$ ) and the $23 \mathrm{~h}$ were recorded in Sandnes 2007

the bat box, when some of the bats left the box at colder and re-entered at warmer temperatures (Table 2). Hibernating soprano pipistrelles were found in the bat box in all winters from December 2015.

Although pipistrelles could be recorded flying in all months of the year, their main active period was from

Table 2 Changing numbers ( $N$ ) of soprano pipistrelles in a bat box with ambient temperature $\left({ }^{\circ} \mathrm{C}\right)$

\begin{tabular}{llll}
\hline Date & $\mathbf{N}$ & ${ }^{\circ} \mathbf{C}$ & Sound \\
\hline 21 Dec & $5-7$ & 7.0 & 5 \\
22 Dec & & & 2 \\
23 Dec & 7 & 4.5 & \\
26 Dec & 2 & -2.2 & \\
27 Dec & 2 & 2.8 & \\
28 Dec 10h & $3-4$ & 3.9 & 4 \\
28 Dec 23h & $4-5$ & 6.4 & 3 \\
29 Dec & $5-6$ & 9.8 & 1 \\
31 Dec & & & \\
1 Jan & $5-6$ & 4.5 & \\
2 Jan & 7 & 6.8 & \\
4 Jan & $7-10$ & -0.4 & \\
\hline
\end{tabular}

Winter recordings made from 21 December 2019 to 4 January 2020 in Frafjord, SW Norway. The ambient temperature was recorded about $8 \mathrm{~m}$ from the box at the time of counting. Sound is the number of minute intervals during which echolocation of flying pipistrelles were recorded by the data-logger late April or first days of May until the middle of October (Fig. 1). Outside this period, the recordings were sparse (Table 1). The major increase in spring activity occurred from 5 May 2018 and 19 April 2020. Consequently, the pipistrelles' main active season lasted 5 to 5.5 months, with a rather abrupt start and end.

At the farm site, pipistrelles were recorded throughout the night and almost every night throughout the main activity season (Fig. 1) with nearly $100 \%$ between sunset and sunrise. There was no clear time-lag between pipistrelle activity and sunset or sunrise (Fig. 1, Table 1). Their activity was centred around the time the sun was at its lowest angle, but marginally skewed towards the evening on some nights. This skew could be $10-15 \mathrm{~min}$. The bats adjusted their activity to sunset and sunrise almost perfectly tracking the changing night length throughout the year (Fig. 1). They thus apparently preferred light levels below $1000 \mathrm{~lx}$, possibly mostly below $500 \mathrm{~lx}$ (Table 1).

Social calls were recorded from April to November (Fig. 2). The vast majority was recorded in August and September, with a few into October. In August and September, the numbers of social call minutes equalled nearly half the total number of pipistrelle echolocation recordings (Fig. 2). The denser area of increased activity in Fig. 1 from the middle of August to late September probably reflects the main mating season, with males patrolling back and forth both calling and hunting.

Most recordings were made around midnight, with social calls following the pattern of the echolocation recordings (Fig. 3). Because the pipistrelle's first emergence tracked the time of sunset, they emerged progressively later until the summer solstice in June and thereafter progressively earlier until November (Fig. 1). In June, the total activity period of the pipistrelles was 5 h $47 \mathrm{~min}$ and in July $7 \mathrm{~h} 22 \mathrm{~min}$ (Table 1 ). This extended to up to about $12 \mathrm{~h}$ in September. At sites in Frafjord other than the main site, the recorded activity period was slightly longer in August (Table 1). The recordings from other sites were skewed slightly later in the night than those from the main site (Fig. 3). Both the absolute earliest record in the evening and the latest record in the morning were made in December 2019, at $1713 \mathrm{~h}$ on the 29 th and at $0916 \mathrm{~h}$ on the 23rd, respectively. Both times were between sunset and sunrise.

\section{Discussion}

This study confirmed that the soprano pipistrelle is an "early riser" compared to most other bats, utilizing the full night between sunset and sunrise [22]. Throughout the year, the bats closely tracked the timing of sunset and sunrise, most notably expanding their nightly activity period in late summer and autumn. They sometimes, but very rarely, started to fly before sunset, but hardly 


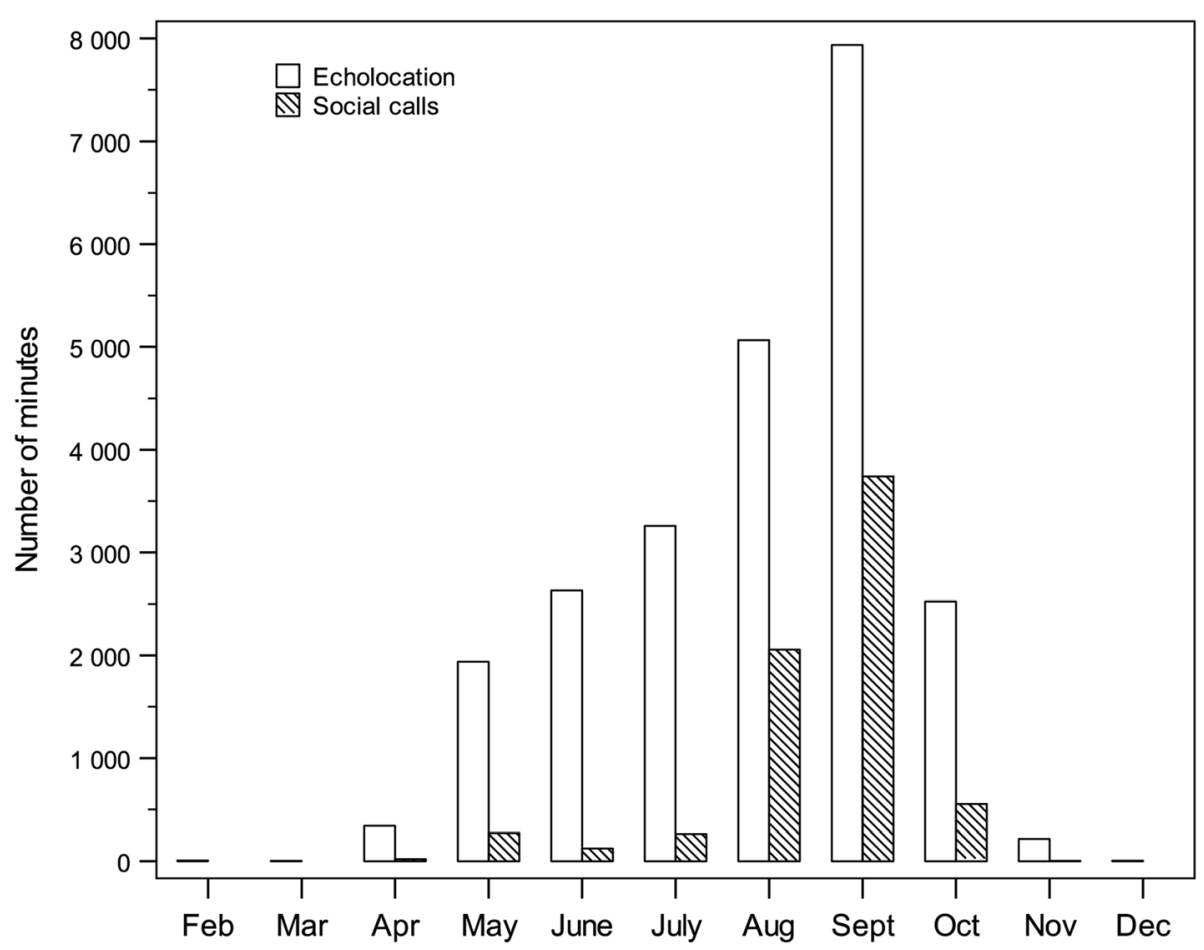

Fig. 2 Number of minutes with recordings of echolocation and social calls of the soprano pipistrelle by month

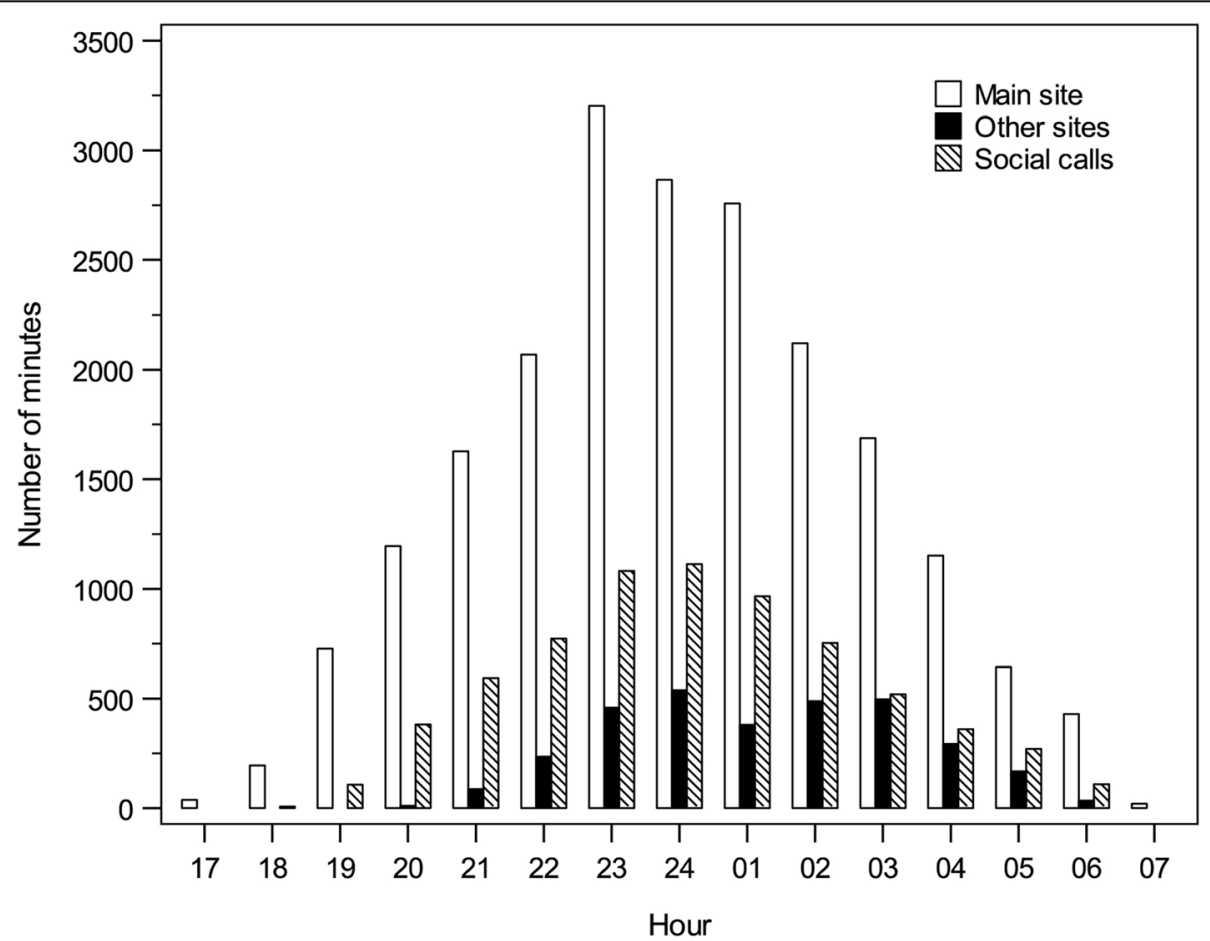

Fig. 3 Number of minutes with recordings of the soprano pipistrelle by hour of the night. Presented are echolocation recordings at the main site, echolocation recordings at other sites and social calls at the main site 
ever flew after sunrise. Consequently, the results from this study did not directly corroborate data from the northern limit of the soprano pipistrelle's distribution in Norway at $62^{\circ} \mathrm{N}(25,21]$ where they sometimes started to fly earlier in the evening relative to sunset. Petrzelková et al. [5] found that light levels at exit varied among roosts of the soprano pipistrelle, but were mostly below $600 \mathrm{~lx}$. The common pipistrelle, on the other hand, appears to emerge from the roost considerably later. At $57^{\circ}$ $13^{\prime} \mathrm{N}$ in Scotland, it emerged 35 min after sunset, in light levels of $15-35 \mathrm{~lx}[5,8]$. A similar result was found at $51^{\circ} 45^{\prime} \mathrm{N}$ in England [11].

This study also confirmed that the soprano pipistrelle hibernated in Frafjord, even in sub-zero temperatures as does the common pipistrelle [31]. Hibernation in bat boxes has also been found further north in western Norway [32], and may be a regular strategy along the south-western coast of Norway where such boxes are available. However, their hibernation, or at least that of some individuals, was not as constant as expected. Flying bats could be encountered in any month of the year, although very rarely in the winter months NovemberMarch. Winter flights could involve both hunting and movement to a different hibernacula [26, 31]. In the mild winters of this region, the soprano pipistrelle appeared to have a flexible winter hibernation strategy. Since the harem in the bat box most likely consisted of one male and several females, it is unlikely that winter movements were restricted to males only. Among the seven bat species recorded in Frafjord, only the soprano pipistrelle flew in November-March (the other species found are Pipistrellus nathusii, Eptesicus nilssonii, Myotis daubentonii, M. mystacinus, Vespertilio murinus and Nyctalus noctula).

Although the exact dates are not known, it is likely that soprano pipistrelle nursery roosts in Frafjord existed from May to early July. The bats then moved to mating roosts (harems) which lasted until the end of September or early October. Winter hibernation lasted from late October to late April, and, at least in the case of the wood-concrete bat box, could occur as a continuation at the harem site. A few bats moved between different sites during the winter months and some also hunted on warmer nights.

The main season of soprano pipistrelle activity in Frafjord was from the last days of April to the middle of October. This is very similar to the common pipistrelle in England [11], but the two species had yet to be separated at the time of that study. It is also similar to Pipistrellus spp. in Northern Ireland [33]. At $50^{\circ} 49^{\prime} \mathrm{N}$ in Germany, the common pipistrelle arrived at the roosts around the middle of May and roost switching by breeding females was common [14]. Maier [11] observed the first volant young around 8 July and, based on that date, estimated that parturition took place around 17 June. In Frafjord, many more recordings of the soprano pipistrelle were made in September than in any other month, which may largely have been due to male song flights. Consequently, the timing of the first flight of young bats could not be determined in this study. The increase in social calls found in August-September was similar but not identical, to the increase found in September-October in Northern Ireland [33, sensu 27]. In one study, the soprano pipistrelle foraged $204 \mathrm{~min}$ per night [34]. In Frafjord, the night was nearly $6 \mathrm{~h}$ long at its shortest in June, almost twice the length of that foraging time. Consequently, the soprano pipistrelle could follow a safe strategy of only flying when the sun was below the horizon, timing its activity in relation to sunset and sunrise. Although this meant some flying in twilight conditions, in the valley this was probably to some extent amended by a mountain shadow.

\section{Conclusions}

Flying soprano pipistrelles were encountered in all months of the year, but their main active season was between late April and late October, or 6-7 months. Very few flights were recorded during December-March, although bats hibernating in a bat box came and left also at this time. Their nightly activity closely tracked sunset and sunrise, with very few recordings outside this period. This implied changes in the length of the bats' hunting period throughout the season, being shortest at midsummer when the energy demands on reproducing females should be large. Male song flights were recorded from April until November, with most recordings in August and September. At this time, males gather harems of females, and such groups may continue to use a bat box for example, well into the winter and hibernation period. It appears that this study is the first to study the activity of this species throughout the year and comprehensively relative to sunset and sunrise. This knowledge should be of importance to conservation and management, which need information both about seasonal activity, habitat preferences, breeding roosts and winter hibernaculas. In Norway, the soprano pipistrelle is classified as of least concern (LC), but little is known about population size or trend.

\section{Methods}

Soprano pipistrelles were studied in Frafjord $\left(58^{\circ} 50^{\prime} \mathrm{N}\right.$ $6^{\circ} 18^{\prime} \mathrm{E}$ ). This is a small valley with steep sides running west to east in Rogaland county, on the SW coast of Norway (Fig. 4). It has a coastal climate with a large annual rainfall, mild winters and little snow.

Bat sounds were recorded with an ultrasound recorder, Wildlife Acoustics SM2Bat (Wildlife Acoustics, USA). This recorder was in operation over more than a year, 


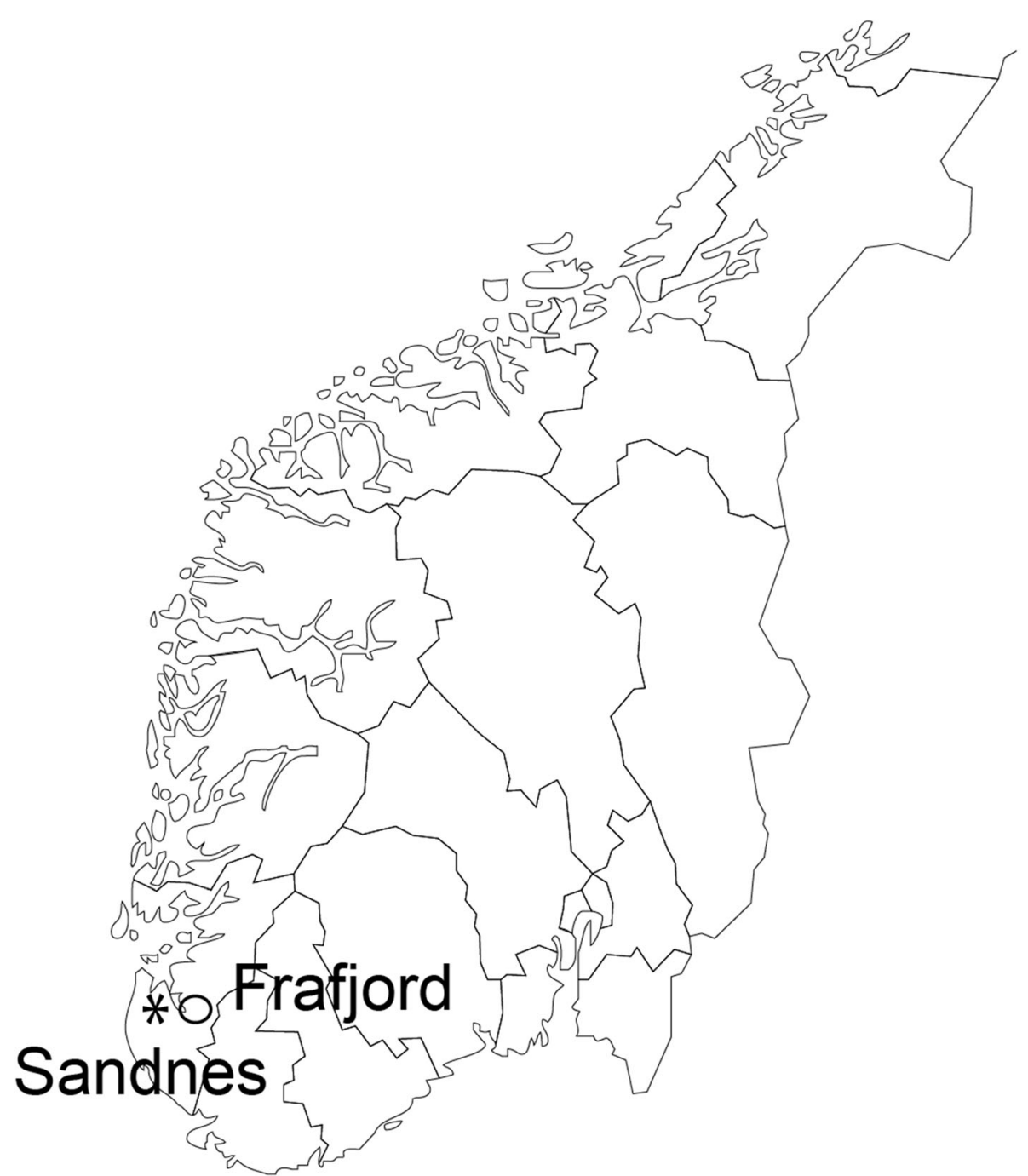

Fig. 4 Map of South Norway with the locations Frafjord (o) and Sandnes (*) marked

from 26 April 2018 to 27 June 2019, at a single site termed the main site (a farm in the central part of the valley, Additional file 1), although the recordings were not fully contiguous. Data are missing from April and May 2019 due to a faulty memory card, hence, this period was covered in 2020 (21 March to 16 June).. The microphone was placed about $3 \mathrm{~m}$ above ground, on the farmhouse and facing a garden, a small road and a field.

In June-July 2016, August 2017, late June-July 2019 and July 2020, ultrasound recordings were made at various other sites (termed "other sites") surrounding and including the main site described above (Additional file 1). This was an attempt to map specific areas particularly used by the bats, as well as their activity. The distance between the outermost sites was $2.7 \mathrm{~km}$. Additionally, some recordings combined with observations were made in December 2019 to January 2020, these are only included in Table 2.
Generally, the recorder was programmed to start 0.5 or $1.0 \mathrm{~h}$ before sunset and ran until the same interval after sunrise (bats were never seen flying in daylight hours). From October to December 2018, the nightly recording program was reduced to around $9 \mathrm{~h}$ from sunset, i.e. the recorder stopped before sunrise, to limit the huge amount of work needed to go through all the files generated. In 2020, the recordings started $1 \mathrm{~h}$ before sunset and ran until $1 \mathrm{~h}$ after sunrise.

Because seven bat species have been recorded in Frafjord, all recordings had to be first identified to species. Files were first automatically scanned in Song Scope (Wildlife Acoustics, USA) using a species-specific identifier. The identified bat emissions were then manually checked and the files further searched by looking at spectrograms throughout the file and species identified. Every minute during which the sound of a soprano pipistrelle was identified represented one case, so that the 
sample size is the number of minutes in which a bat was identified (Additional file 2). Social calls (characteristic low-frequency calls, e.g. 29) were identified to the minute by the same procedure. Multiple soprano pipistrelles recorded simultaneously were ignored and recorded as $1 \mathrm{~min}$.

Principally, pipistrelle echolocation calls above 48 $\mathrm{kHz}$ were identified to be from a soprano pipistrelle $[28,35]$. A few recordings of Nathusius' pipistrelle Pipistrellus nathusii were also made in Frafjord, but this species appeared to be a rare visitor. Soprano and Nathusius' pipistrelles can relatively safely be distinguished by the frequency of their echolocation calls $[28,36]$. The common pipistrelle was most likely absent in Frafjord.

Light level data were not collected in Frafjord, but some data collected at a site $32 \mathrm{~km}$ from Frafjord, at the city of Sandnes ( $58^{\circ} 51^{\prime} \mathrm{N} 5^{\circ} 44^{\prime} \mathrm{E}$, Fig. 4), in 2007 were used for comparison. This location is open space, but surrounded by houses. These data were collected using a Pace Scientific Inc. Pocket logger XR440, with the sensor placed about $5 \mathrm{~m}$ above the ground. Recordings were made every $10 \mathrm{~min}$ through all $24 \mathrm{~h}$. This only gives an approximation of the levels in Frafjord, and is only used to indicate maximum possible levels at sunset and sunrise.

The timing of the sunset, sunrise and sun at its lowest inclination angle in the north were downloaded from https://www.timeanddate.no/ (September 2019) for Sandnes (Fig. 4). All data were adjusted to Norwegian summer time (daylight saving time, UTC + $2 \mathrm{~h}$ ). Because bat activity was centred around midnight, the presentations are based on "night" rather than "day". Each night crosses two dates, but was assigned to its start date. Because sunset and sunrise are only 2 min earlier in Frafjord than in Sandnes, this small difference was ignored.

The pipistrelles hunted so regularly at the farm that a roost most likely existed nearby. Two roosts were known some $300 \mathrm{~m}$ away, but neither was a nursery roost with young. One was in a wood-concrete bat box mounted in a tree, with an open bottom that made inspection possible without disturbing the bats. Sometimes the bat box and the other roost was inspected from below with a small torch and the number of pipistrelles counted. These counts were only approximate, as it was difficult to separate individual bats when they clumped together. The combined number of pipistrelles in these roosts was small, maximum around ten bats. Close to the two roosts mentioned, a third roost site was found in a stack of wooden and polystyrene boxes, about $1 \mathrm{~m}$ high. In the autumn 2019, one dead pipistrelle was found along with a large number of droppings indicating that this unlikely site may have been a nursery roost in the summer 2019.

\section{Supplementary Information}

The online version contains supplementary material available at https://doi. org/10.1186/s40850-021-00065-x.

Additional file 1. Topographical map of the Frafjord valley, southwest Norway, with all locations were the Wildlife Acoustics SM2Bat recorder was applied. Circle: main site, *: other sites.

Additional file $\mathbf{2}$ Dataset by month and year for Pipistrellus pygmaeus recorded in Frafjord, Norway. (XLS 39 kb)

\section{Acknowledgements}

This study was only made possible through the efforts of Per Gunnar Frafjord in keeping the data-logger in operation through more than a year. Rob Barrett greatly improved the English style and spelling. Thanks to both of you.

\section{Author's contributions}

The author designed the study, collected some of the data, performed the analysis and wrote the manuscript. Per Gunnar Frafjord collected most of the data with a datalogger provided and programmed by the author. The author(s) read and approved the final manuscript.

\section{Funding}

This study had no funding.

\section{Availability of data and materials}

The dataset supporting the conclusions of this article is included within the article and in one additional file.

Ethics approval and consent to participate

No animal was trapped or handled.

Consent for publication

Not applicable.

\section{Competing interests}

No competing interests.

Received: 25 November 2020 Accepted: 27 January 2021

Published online: 09 February 2021

\section{References}

1. Jones $G$, Rydell J. Foraging strategy and predation risk as factors influencing emergence time in echolocating bats. Phil Trans Royal Soc Lond B. 1994; 346:445-55

2. Rydell J, Speakmann JR. Evolution of nocturnality in bats: potential competitors and predators during their early history. Biol J Linnean Soc. 1995;54:183-92.

3. Voigt CC, Lewanzik D. Trapped in the darkness of the night: thermal and energetic constraints of daylight flight in bats. Proc Royal Soc Lond B. 2011; 278:2311-7 https://doi.org/10.1098/rspb.2010.2290.

4. Duvergé $\mathrm{PL}$, Jones $\mathrm{G}$, Rydell J, Ransome RD. Functional significance of emergence timing in bats. Ecography. 2000;23:32-40.

5. Petrzlková K, Downs NC, Zukal J, Racey PA. A comparison between emergence and return activity in pipistrelle bats Pipistrellus pipistrellus and $P$. pygmaeus. Acta Chiropt. 2006:8:381-90.

6. Mikula P, Morelli F, Lucan RK, Jones DN, Tryjanowski P. Bats as prey of diurnal birds: a global perspective. Mamm Rev. 2016:46:160-74 https://doi. org/10.1111/mam.12060.

7. Altringham JD. Bats: from evolution to conservation. Oxford: Oxford University Press; 2011.

8. Swift S. Activity patterns of pipistrelle bats (Pipistrellus pipistrellus) in northEast Scotland. J Zool (Lond). 1980;190:285-95.

9. Bullock DJ, Combes BA, Eales LA. Analysis of the timing and pattern of emergence of the pipistrelle bat (Pipistrellus pipistrellus). J Zool (Lond). 1987; 211:267-74

10. Gerell R, Lundberg K. Sexual differences in survival rates of adult pipistrelle bats (Pipistrellus pipistrellus) in South Sweden. Oecologia. 1990;83:401-4.

11. Maier C. Activity patterns of pipistrelle bats (Pipistrellus pipistrellus) in Oxfordshire. J Zool (Lond). 1992;228:69-80. 
12. Speakman JR, Bullock DJ, Eales LA, Racey PA. A problem defining temporal pattern in animal behavior: clustering in the emergence behaviour of bats from maternity roosts. Anim Behav. 1992;43:491-500.

13. Speakman JR, Irwin N, Tallach N, Stone R. Effect of roost size on the emergence behaviour of pipistrelle bats. Anim Behav. 1999;58:787-95.

14. Feyerabend F, Simon M. Use of roosts and roost switching in a summer colony of $45 \mathrm{kHz}$ phonic type pipistrelle bats (Pipistrellus pipistrellus Schreber, 1774). Myotis. 2000;38:51-9.

15. Sendor T, Simon M. Population dynamics of the pipistrelle bat: effects of sex, age and winter weather on seasonal survival. J Anim Ecol. 2003;72:308-20.

16. Winchell JM, Kunz T. Day-roosting activity budgets of the eastern pipistrelle bat, Pipistrellus subflavus (Chiroptera: Vespertilionidae). Can J Zool. 1995;74:431-41.

17. Andrews PT, Crump RG, Harries DJ, Andrews MM. Influence of weather on a population of soprano pipistrelle bats in West Wales, UK: a 20 year study estimates population viability. End Species Res. 2016:30:19-28 https://doi. org/10.3354/esro0720.

18. Jones G, van Pariij SM. Bimodal echolocation in pipistrelle bats: are cryptic species present? Proc Royal Soc Lond B. 1993;251:119-25.

19. van der Kooij J, Olsen KM. Kartlegging og overvåking av flaggermus i Norge - Forpliktelser, metodikk og historikk. Norsk Zool For, Rapp. 2012;15:85.

20. Michaelsen TC, Jensen $\mathrm{KH}$, Högstedt G. Topography as a limiting distributional factor in the soprano pipistrelle at its latitudinal extreme. Mamm Biol. 2011;76:295-301 https://doi.org/10.1016/j.mambio.2010.12.004

21. Michaelsen TC, Jensen $\mathrm{KH}$, Högstedt G. Does light conditions affect the habitat use of soprano pipistrelles Pipistrellus pygmaeus at the species northern extreme? Acta Chiropt. 2018;20:377-85 https://doi.org/10.3161/1 5081109ACC2018.20.2.009.

22. Russo D, Cistrone L, Garonna AP, Jones G. The early bat catches the fly: daylight foraging in soprano pipistrelles. Mamm Biol. 2011;73:87-9 https:// doi.org/10.1016/j.mambio.2009.08.002.

23. Davidson-Watts I, Jones G. Differences in foraging behaviour between Pipistrellus pipistrellus (Schreiber, 1774) and Pipistrellus pygmaeus (leach, 1825). J Zool (Lond). 2006;268:55-62.

24. Michaelsen $\mathrm{TC}$, Jensen $\mathrm{KH}$, Högstedt $\mathrm{G}$. Roost selection in pregnant and lactating soprano pipistrelles (Pipistrellus pygmaeus leach, 1825) at the species northern extreme: the importance of warm and safe roosts. Acta Chiropt. 2014:16:349-57 https://doi.org/10.3161/150811014X687305.

25. Michaelsen TC. Spatial and temporal distribution of bats (Chioptera) in bright summer nights. Anim Biol. 2016;66:65-80 https://doi.org/10.1163/1 5707563-00002488

26. Avery MI. 1985. Winter activity of pipistrelle bats. J Animal Ecol. 1985;54:721-38.

27. Gerell-Lundberg K, Gerell R. The mating behaviour of the pipistrelle and the Nathusius' pipistrelle (Chiroptera) - a comparison. Folia Zool. 1994;43:315-24.

28. Russ J. British bat calls. A guide to species identification. Exeter: Pelagic Publishing; 2012.

29. Barlow K, Jones G. Function of pipistrelle social calls: field data and a playback experiment. Anim Behav. 1997;1997:991-9.

30. Götze S, Denziger A, Schnitzler H-U. High frequency social calls indicate food source defense in foraging common pipistrelle bats. Scientific Reports. 2020:10:5764. https://doi.org/10.1038/s41598-020-62743-z.

31. Speakman JR, Racey PA. Hibernal ecology of the pipistrelle bat: energy expenditure, water requirements and mass loss, implications for survival and the function of winter emergence flights. J Anim Ecol. 1989;58:797-813.

32. Michaelsen TC, Olsen O, Bjordal H. Funn av dvergflaggermus Pipistrellus pygmaeus i ynglekolonier om vinteren. Fauna. 2011;64:88-92.

33. Russ JM, Brifa M, Montgomery WI. Seasonal patterns in activity and habitat use by bats (Pipistrellus spp. and Nyctalus leisleri) in Northern Ireland, determined using a driven transect. J Zool, Lond. 2003;259:289-99 https:// doi.org/10.1017/S0952836902003254

34. Nicholls B, Racey PA. Contrasting home-range size and spatial partitioning in cryptic and sympatric pipistrelle bats. Behav Ecol Sociobiol. 2006;61:13142 https://doi.org/10.1007/s00265-006-0244-7.

35. Barataud M. Acoustic ecology of European bats. Species identification, study of their habitats and foraging behaviour. Paris: Biotope, Méze; Muséum national d'Histoire naturelle (Inventraires et biodiversité series); 2015.

36. Necknig V, Zahn A. Between-species jamming avoidance in pipistrelles? J Com Physiol A. 2010. https://doi.org/10.1007/s00359-010-0586-5.

\section{Publisher's Note}

Springer Nature remains neutral with regard to jurisdictional claims in published maps and institutional affiliations.

\section{Ready to submit your research? Choose BMC and benefit from:}

- fast, convenient online submission

- thorough peer review by experienced researchers in your field

- rapid publication on acceptance

- support for research data, including large and complex data types

- gold Open Access which fosters wider collaboration and increased citations

- maximum visibility for your research: over $100 \mathrm{M}$ website views per year

At $\mathrm{BMC}$, research is always in progress.

Learn more biomedcentral.com/submissions 